УДК 616.33+616.342-002.4 4-06-08 9

DOI 10.11603/2414-4533.2016.3.6798

(С А. Д. БЕДЕНЮК, Е. В. ЯКУБЕНКО

ДВН3 “Тернопільський державний медичний університет імені І. Я. Горбачевського", К3 ТОР "Тернопільська університетська лікарня"

\title{
Вдосконалені методики протистенотичних анастомозів кінець в кінець у шлунковій хірургї
}

\author{
A. D. BEDENYUK, E. V. YAKUBENKO \\ I. Horbachevsky Ternopil State Medical University \\ Ternopil University Hospital
}

\section{IMPROVED METHODS OF ANTISTENOSIS “END TO END” ANASTOMOSIS IN GASTRIC SURGERY}

\begin{abstract}
На 21 органокомплексах трупів людей розроблено техніку виконання різних варіантів протистенотичних анастомозів кінець в кінець, які успішно впроваджено в клінічну практику при традиційних і трубчастих резекціях шлунка (ТРШ) (рис. 1): 1) з кутоподібним (кутовим) посіченням стінок анастомозова-них органів (5 випадків) - рис. 1, а; 2) з S-подібним посіченням анастомозованих країв (5 випадків) - рис. 1, б; 3 ) з дугоподібним посіченням країв органів (5 випадків), що анастомозуються, - рис. 1, в, які дозволили нам апробувати в кліні-ці експериментальні напрацювання з вивченням стану судинно-нейроклітинних мікрокомплексів інтрамуральних гангліїв міжм'язового нервового сплетення стінок шлункової кукси на капілярно-нейроклітинному рівні в різні віддалені терміни після клиноподібно-трубчастих резекцій (КТРШ) 1/3 та 2/3 шлунка з різними варіантами відновлення шлунково-кишкового тракту. Підтверджено ефективність розроблених методик операцій.

On 21 human body organocomplexes there were developed the technique of different options of antistenotic "end to end" anastomosis, which were successfully introduced into clinical practice in traditional and tubular stomach resections (TSR) (Fig. 1): 1) with angulate (angular) excision of walls of anastoming organs (5 cases) Fig. 1, a; 2) with S-shaped excision of anastoming edges (5 cases) - Fig. 1, б; 3) with arched excision of edges (5 cases), Fig. 1, в, which allowed us to test in clinic these experimental developments with the study of state vascular-neurocell microcomplexes of intramural ganglia of intramuscular nerve plexus of walls of gastric stump on the capillary-neurocell level in different long term after (WTLR) wedge-tubular resections of $1 / 3$ and $2 / 3$ of the stomach restoration with different versions of the gastrointestinal tract. The effectiveness of developed methods of operations was confirmed.
\end{abstract}

Постановка проблеми і аналіз останніх досліджень та публікацій. Проблема ефективного анастомозування трубчастих органів травного тракту продовжує залишатися складною, дискусійною і остаточно не вирішеною [1, 2].

На думку ряду хірургів [3, 5-8] при накладенні прямого анастомозу кінець в кінець дворядним швом за традиційною класичною методикою відбувається звуження просвіту формованого співустя, в середньому, на 20-28 \% внутрішнього просвіту (діаметра) за рахунок внутрішньопросвітного інвагінаційного тканинного валика. Величина зануреного внутрішньопросвітного тканинного валика багато в чому залежить від техніки хірурга, правильного вибору виду шва в кожному конкретному випадку операційного втручання. Тому в ряді випадків при формуванні анастомозу за типом кінець в кінець у ранньому післяопераційному періоді спостерігаються явища анастомозиту і часткової непрохідності зони анастомозу [3, 7, 8], зумовлених запаленням і набряком у ділянці швів формованого співустя і зануреного внутрішньопросвітного тканинного валика, що звужує просвіт і порушує евакуаційно-транспортну функцію анастомозу $[4,8]$. Так, при формуванні прямого гастродуоденоанастомозу (ГДА) за традиційною методикою (дворядним швом: кетгут, шовк або капрон) при резекції шлунка за Більрот I явища анастомозиту в ранньому післяопераційному періоді виявлено нами у кожного 4-5-го оперованого хворого, що склало 21,7 \% (у 5 пацієнтів із 23 оперованих) навіть у руках досвідчених хірургів. Дані хворі склали контрольну групу. Звуження просвіту формованого співустя послужило відмовою ряду хірургів від застосування прямого анастомозу кінець в кінець при резекції.

Мета роботи: розширення можливостей формування прямого анастомозу кінець в кінець на трубчастих органах шлунково-кишкового тракту (ШКТ): ГДА і міжкишкового анастомозу (MКА) 
шляхом проведення секційних, експериментальних та клінічних досліджень для вдосконалення методик формування анастомозів кінець в кінець.

Матеріали і методи. На ранніх етапах проведено секційні дослідження на 21 трупі й органокомплексах трупів людей, на яких відпрацьовано техніку формування прямого ГДА і МКА за типом кінець в кінець за класичною (традиційною) методикою (6 випадків) і в 14 випадках застосовано вдосконалені методики формування анастомозу кінець в кінець: 1) з дугоподібним посіченням країв органів (5 випадків), що анастомозуються; 2) з кутоподібним (кутовим) посіченням стінок анастомозованих органів (5 випадків) і 3) $3 \mathrm{~S}$-подібним посіченням анастомозованих країв (5 випадків), які дозволили нам апробувати в клініці експериментальні напрацювання з вивченням стану судинно-нейроклітинних мікрокомплексів інтрамуральних гангліїв міжм’язового нервового сплетення стінок шлункової кукси на капілярнонейроклітинному рівні в різні віддалені терміни після клиноподібно-трубчастих резекцій 1/3 та 2/3 шлунка 3 різними варіантами відновлення шлунково-кишкового тракту.

Результати досліджень та їх обговорення. Впровадження експериментальних розробок в клінічну практику здійснено на 7 хворих при формуванні ГДА кінець в кінець при традиційних резекціях шлунка і ТРШ у 30_хворих, яких оперують з приводу ускладнених форм гастродуоденальних виразок (ГДВ). Загальні відомості про характер проведених експериментальних і клінічних досліджень представлено в таблиці 1.

1. Методика формування прямого ГДА або MKA 3 кутовим посіченням країв органів, що анастомозуються, здійснена і впроваджена в клінічній практиці в 11 хворих (рис. 1, а). Операцію виконували таким чином: накладали на краї стінок, що анастомозувалися, прямі гемостатичні затискачі Більрота під кутом $120^{\circ}$ до середини осі просвіту органів, що анастомозувалися, і сікли краї передньої та задньої стінок органів, що анас- томозувалися, під кутом по краях бранш затискачів. Краї розрізу стінок обробляли 5 \% настоянкою йоду. Верхній і нижній краї стінок органів, що анастомозуються, брали на шви-трималки.

За допомогою швів-трималок зіставляли краї стінок органів, що анастомозувалися, знімали затискачі, здійснювали гемостаз у рані. Краї стінок анастомозованих органів фіксували в поперечному напрямі за допомогою швів-трималок. При необхідності аспірували за допомогою електровідсмоктування вміст просвіту органів, що анастомозуються. Накладали вузлові капронові шви (зовнішній ряд) на задню губу анастомозу. Надалі техніка формування анастомозу істотно не відрізнялася від техніки попередньої методики, описа-

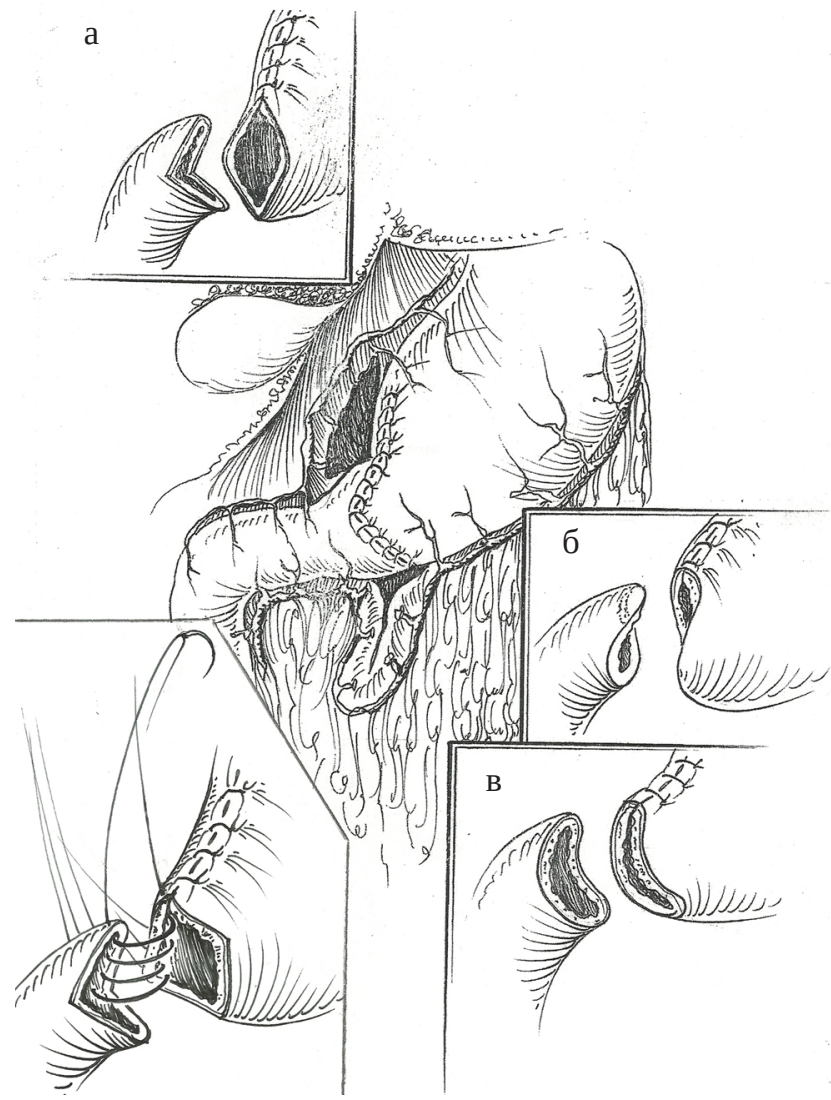

Рис. 1. Види анастомозів: а - кутоподібний анастомоз; б - S-подібний анастомоз; в - дугоподібний анастомоз.

Таблиця 1. Розподіл хворих залежно від способу резекції шлунка і методу формування протистенотичного анастомозу кінець в кінець

\begin{tabular}{|c|c|c|c|c|c|}
\hline \multirow{4}{*}{$\begin{array}{c}\text { Методики резекцій } \\
\text { шлунка }\end{array}$} & \multicolumn{5}{|c|}{ Методики формування анастомозів кінець в кінець } \\
\hline & \multirow{3}{*}{$\begin{array}{l}\text { класична } \\
\text { методика }\end{array}$} & \multicolumn{4}{|c|}{ вдосконалені методики } \\
\hline & & \multicolumn{4}{|c|}{ види висікання країв стінок анастомозованих органів } \\
\hline & & дугоподібне & кутоподібне & S-подібне & всього \\
\hline Резекція шлунка за Більрот I & 7 & 12 & 11 & 7 & 37 \\
\hline Всього & 7 & 12 & 11 & 7 & 37 \\
\hline
\end{tabular}


ної вище, 3 тією лише різницею, що при цій методиці операції з кутовим висіченням країв органів, що анастомозуються, відбувається значніше збільшення периметра зшиваних стінок, що дозволяє як внутрішній гемостатичний шов використати безперервний обвивний гемостатичний адаптуючий кетгутовий шов тонкою ниткою без загрози стенозування утвореного співустя.

Накладення безперервного гемостатичного кетгутового шва (як внутрішнього ряду швів) на 7-10 хв прискорює виконання операції, підвищує iї надійність та ефективність.

2. Методика формування прямого анастомозу 3 S-подібним посіченням країв органів, що анастомозуються (рис. 1, б), здійснена і впроваджена в клінічну практику при резекціях шлунка (7 хворих (див. табл. 1).

Операцію виконували таким чином. Після резекції шлунка або пошкодженої ділянки кишки зближували краї стінок органів, що анастомозувалися. На верхній і нижній краї органів, що анастомозуються, накладали шви-трималки. Затискачі знімали. При необхідності здійснювали аспірацію вмісту з просвіту органів, що анастомозувалися. Проводили додаткове посічення країв передніх і задніх стінок анастомозованих органів за допомогою ножиць Купера і анатомічних пінцетів по S-подібній лінії у вигляді взаємно конгруентних сторін, здійснювали гемостаз у рані. Фіксували краї стінок органів, що анастомозувалися, в поперечному напрямі і формували анастомоз дворядним швом за вищеописаною методикою.

У результаті проведених маніпуляцій досягали збільшення просвіту формованого анастомозу за рахунок збільшення його периметра на 1,52,8 см (25-46 \%), що попереджало стенозування формованого анастомозу. Слід зазначити, що S-подібне посічення країв стінок анастомозованих органів значною мірою попереджало не тільки збільшення периметра зшиваних стінок, але i розвиток анастомозиту за рахунок S-подібного зміщення внутрішньопросвітного зануреного тканинного валика передньої і задньої губи утворюваного співустя. Проведені ендоскопічні дослідження (фіброгастродуоденоскопія) і рентгенологічне дослідження евакуаторної функції шлункової кукси та вивчення пасажу барієвої суспензії по кишечнику виявили задовільну прохідність сформованих протистенотичних анастомозів.

Випадків анастомозиту і недостатності швів формованого співустя в післяопераційному періоді не виявлено, що підтверджує функціональну надійність сформованих анастомозів за вдосконаленими методиками.
3. Методика формування ГДА і МКА кінець в кінець 3 дугоподібним посіченням країв органів, що анастомозуються, здійснена і впроваджена в клінічну практику в 12 хворих (рис. 1, в). Операцію виконували таким чином. Накладали на краї шлункових кукс, що анастомозувалися, і дванадцятипалої кишки (ДПК) спеціальні дугоподібно зігнуті гемостатичні затискачі (увігнутою стороною у бік органів, що анастомозуються). Після резекції шлунка або ділянки кишки на верхній і нижній краї анастомозованих стінок накладали шви-трималки. Додатково сікли передню і задню стінки органів, що анастомозувалися, по увігнутій стороні бранш накладених затискачів. Затискачі знімали. Гемостаз у рані. При необхідності аспірували за допомогою електровідсмоктування вміст просвіту анастомозованих органів. За допомогою трималок краї стінок анастомозованих органів розводили в поперечному напрямку і формували задню губу ГДА або МКА вузловими капроновими серозно-м'язовими швами (зовнішній ряд швів задньої губи анастомозу) по дугоподібно зігнутій лінії, зближуючи анастомозовані стінки за допомогою затискачів. Надлишок стінок органів, що анастомозуються, зрізували скальпелем по увігнутій стороні бранш затискачів, краї зрізу обробляли йодом, затискачі знімали. Здійснювали гемостаз у рані. При необхідності аспірували за допомогою електровідсмоктування вміст просвіту органів, що анастомозуються. Фіксували краї стінок анастомозованих органів за допомогою швів-трималок у поперечному напрямі.

Формували внутрішній ряд швів (тонкий кетгут або капрон) на задню губу анастомозу через усі шари адаптуючими швами вузликами всередину просвіту. Потім формували передню губу анастомозу (внутрішній ряд - адаптуючі кетгутові шви з вузликами всередину просвіту, зовнішній ряд - серозно-м’язові вузлові шви). Діаметр анастомозу не перевищував 3 см.

Висновки. 1. Вдосконалені нами методики формування прямого гастродуоденоанастомозу кінець в кінець $€$ надійним та ефективним втручанням.

2. Розроблені методики операції прості в технічному виконанні, надійно запобігають звуженню формованого співустя за рахунок збільшення периметра зшиваних стінок органів, що анастомозуються.

3. Успішна експериментально-клінічна апробація вдосконалених методик протистенотичних анастомозів кінець в кінець дозволяє рекомендувати їх для ширшого застосування в клінічній практиці, плановій та ургентній шлунково-кишковій хірургії. 


\section{З ДОСВІДУ РОБОТИ}

\section{СПИСОК ЛІТЕРАТУРИ}

1. Буценко В. Н. Профилактика несостоятельности швов анастомоза конец в конец / В. Н. Буценко // Избранные труды по экстренной хирургии. - Донецьк, 1992. - С. 90-93.

2. Василенко Л. И. Сравнительная оценка усовершенствованных способов трубчатых резекций желудка в лечении гастродуоденальних язв : автореф. дис. на соискание учёной степени д-ра мед. наук / Л. И. Василенко. - СПб., 1993. - 43 с. 3. Шляхи підвищення ефективності формування конце-концевих анастомозів в хірургії органів шлунково-кишкового тракту / Василенко Л. І., Корнієнко А. М., Епіфанцев А. А., Якубенко Є. В. : матеріали III, ювілейної навч.-метод. конференції завідувачів кафедр хірургічних хвороб стоматологічних факультетів медичних вузів України. - Полтава, 1999. - С. 82-84. 4. Кондратенко П. Г. Эффективность консервативных мероприятий в предупреждении рецидивов гастродуоденальных кровотечений / П. Г. Кондратенко, Е. Е. Раденко // Українский журнал хірургії. - 2008. - № 1. - С. 29-32.

5. Cheung F. K. Management of massive peptic ulcer bleeding / F. K. Cheung, J. Y. Lau // Gastroenterol Clin North Am. - 2009.
- Vol. 3, № 38. - P. 231-243.

6. Круглов В. Диагноз: болезни желудка / В. Круглов. СПб. : Феникс, 2010. - 160 с.

7. Язвенная болезнь желудка и двенадцатиперстной кишки. - СПб. : АСТ, Сова, ВКТ, 2009. - 128 с.

8. Попова Ю. Язвенная болезнь желудка. Самые эффективные методы лечения / Ю. Попова. - СПб. : Крылов, 2010. -128 c.

9. Кобозева Е. И. Язвенная болезнь. Лучшие методы лечения / Е. И. Кобозева. - СПб. : Вектор, 2008. - 128 с.

10. Савельев В. С. Руководство по неотложной хирургии органов брюшной полости / В. С. Савельев. - М., 2004.

11. Частная хирургия : учебник для мед. вузов / под ред. Ю. Л. Шевченко : в 2 т. - СПб., 1998.

12. 50 лекций по хирургии / под ред. В. С. Савельева. - М. : Медиа Медика. - 2003. - 406 с.

13. Бурых М. П. Общие основы технологии хирургических операций / М. П. Бурых. - Ростов-на-Дону : Феникс, 1999. 544 c.

Отримано 02.08.16 